\title{
ANALISIS FAKTOR-FAKTOR PENERIMAAN DAN NIAT KEBERLANJUTAN PENGGUNAAN PORTAL AKADEMIK SIAKAD STMIK AKAKOM MENGGUNAKAN TAM SERTA MODEL DeLONE DAN McLEAN
}

\author{
Sur Yanti ${ }^{1)}$, Henry Nugroho ${ }^{2)}$ \\ Sistem Informasi, STMIK AKAKOM \\ Jl. Raya Janti Karang Jambe No. 143 Yogyakarta 55198 \\ e-mail: yanti.pietreyz@gmail.com ${ }^{1)}$, fxhenry88@gmail.com ${ }^{2)}$
}

\begin{abstract}
ABSTRAK
Portal Akademik SIAKAD STMIK AKAKOM dengan alamat siakad.akakom.ac.id, dibangun dengan tujuan meningkatkan kualitas kinerja dan pelayanan serta sarana interaksi akademis antara dosen, mahasiswa serta bagian akademik berbasis teknologi informasi. Evaluasi kesuksesan penerapannya sangat diperlukan agar selalu dapat memenuhi tujuannya. Berdasarkan penelitian sebelumnya dan dasar teori TAM serta model DeLone dan McLean maka peneliti membuat model untuk menganalisa faktor-faktor penerimaan dan niat keberlanjutan penggunaan SIAKAD STMIK AKAKOM. Alat analisa yang digunakan adalah PLS 3.0 TAM menjelaskan faktor-faktor perilaku pengguna komputer berlandaskan kepercayaan, sikap, keinginan, dan hubungan perilaku pengguna. Model DeLone dan McLean merupakan model kesuksesan sistem informasi dengan tiga bagian instrumen, pertama yang digunakan untuk mengukur keberhasilan teknis yaitu kualitas sistem, kedua ukuran kesuksesan semantik yaitu kualitas informasi, dan ketiga ukuran kesuksesan efektivitas sistem informasi yaitu penggunaan, kepuasan pemakai, dampak individual dan dampak organisasional.Hasil penelitian empiris menunjukkan variabel Kualitas Informasi dan Kualitas Sistem berpengaruh terhadap Kepuasan Pengguna SIAKAD STMIK AKAKOM, sedangkan Niat keberlanjutan menggunakan SIAKAD di STMIK AKAKOM ditentukan Variabel Kepuasan Pengguna.
\end{abstract}

Kata Kunci :Portal Akademik, Technology Acceptance Model, DeLone and Mclean

\begin{abstract}
Academic Portal SIAKAD STMIK AKAKOM with address siakad.akakom.ac.id, was built with the aim of improving the quality of performance and services as well as the means of academic interaction between lecturers, students and academic departments based on information technology. Evaluate the success of its application is necessary to always meet its objectives. Based on previous research and basic theory of TAM and DeLone and McLean model hence researcher make model to analyze acceptance factors and intention of sustainability use SIAKAD STMIK AKAKOM. Analyzer used is PLS 3.0. TAM describes the behavioral factors of computer users based on the beliefs, attitudes, intention, and user behaviour relationship. The DeLone and McLean model is an information system success model with three parts of the instrument, the first used to measure the technical success of the system quality, the two measures of semantic success ie the quality of information, and the three measures of effective information system is use, user satisfaction, individual impact and organizational impact. The results of empirical research indicate variable of Information Quality and System Quality that affect the User Satisfaction towards SIAKAD STMIK AKAKOM, while the sustainability intention using SIAKAD STMIK AKAKOM determined by User Satisfaction variable.
\end{abstract}

Keywords: Academic Portal, Technology Acceptance Model, DeLone and Mclean

\section{PENDAhUluan}

$\mathrm{T}$ leknologi informasi memiliki peran yang sangat penting dalam proses bisnis maupun dalam kegiatan operasional suatu organisasi, sehingga diperlukan pengukuran kesuksesan penerapannya dalam proses bisnis ataupun dalam organisasi. Terdapat beberapa model yang dapat dipergunakan untuk mengukur kesuksesan penerapan teknologi informasi, seperti Technology Acceptance Model (TAM) serta Model DeLone dan McLean.

Model TAM dikembangkan olehDavis[1], pada tahun1986dengan dasar suatu teori psikologis, untuk menjelaskan perilaku pengguna komputer yaitu berlandaskan pada kepercayaan (belief), sikap (attitude), keinginan (intention), dan hubungan perilaku pengguna (user behaviour relationship). Tujuan model TAM adalah menjelaskan faktor-faktor utama dari perilaku pengguna terhadap penerimaan pengguna teknologi. DeLone dan McLean[2]mengembangkan suatu model parsimoni yang disebut model kesuksesan sistem informasi DeLone \& McLean (D\&M Information System Success Model), dengan 3 (tiga) bagian instrumen yang digunakan untuk mengukur keberhasilan teknis, kesuksesan semantik, dan efektivitas kesuksesan sistem informasi. Ukuran keberhasilan teknis adalah kualitas sistem (system quality) yang memperhatikan faktor teknis dari sistem dengan menganalisa apakah sistem memiliki karakteristik yang tepat untuk menghasilkan informasi yang baik. Ukuran kesuksesan semantik adalah Kualitas informasi (information quality), sedangkan ukuran 
kesuksesan efektivitas sistem informasi adalah penggunaan (use), kepuasan pemakai (user satisfaction), dampak individual (individual impact) dan dampak organisasional (organizational impact).

STMIK AKAKOM sebagai salah satu perguruan tinggi dibidang informatika mengembangkan suatu portal akademik yaitu Sistem Informasi Akademik STMIK AKAKOM atau disebut dengan SIAKAD STMIK AKAKOM dengan alamat siakad.akakom.ac.id. Pengguna SIAKAD STMIK AKAKOMterdiri dari 3 jenis yaitu administrator, dosen dan mahasiswa. Berbagai aktivitas seperti penyampaian materi, tugas, jadwal serta nilai mahasiswa dapat dilakukan secara cepat dan efektif dengan menggunakan sarana tersebut.SIAKAD STMIK AKAKOM terbagi kedalam 2 (dua) menu yaitu Academics dan Virtual Class. Menu Academics memiliki dari sub menu halaman depan, panduan, profil, informasi mata kuliah ditawarkan, mata kuliah diampu, bimbingan akademik, pengelolaan nilai, workshop dan ubah password. Menu yang kedua yaitu Virtual Class memiliki sub menu materi kuliah, tugas kuliah, agenda kelas, agenda pribadi, file sharing, referensi, dan panduan.

\section{METODE}

Koefisien-koefisien di model empiris menunjukkan hubungan kausal antara variabel-variabel. Hubunganhubungan kausal ini menunjukkan hipotesis-hipotesis yang akan diuji. Penelitian ini dirancang untuk menguji model multiple relationship antar variabeldengan melibatkan banyak variabel. Model penelitian empirik yang akan digunakan tampak dalam Gambar 1. berikut.

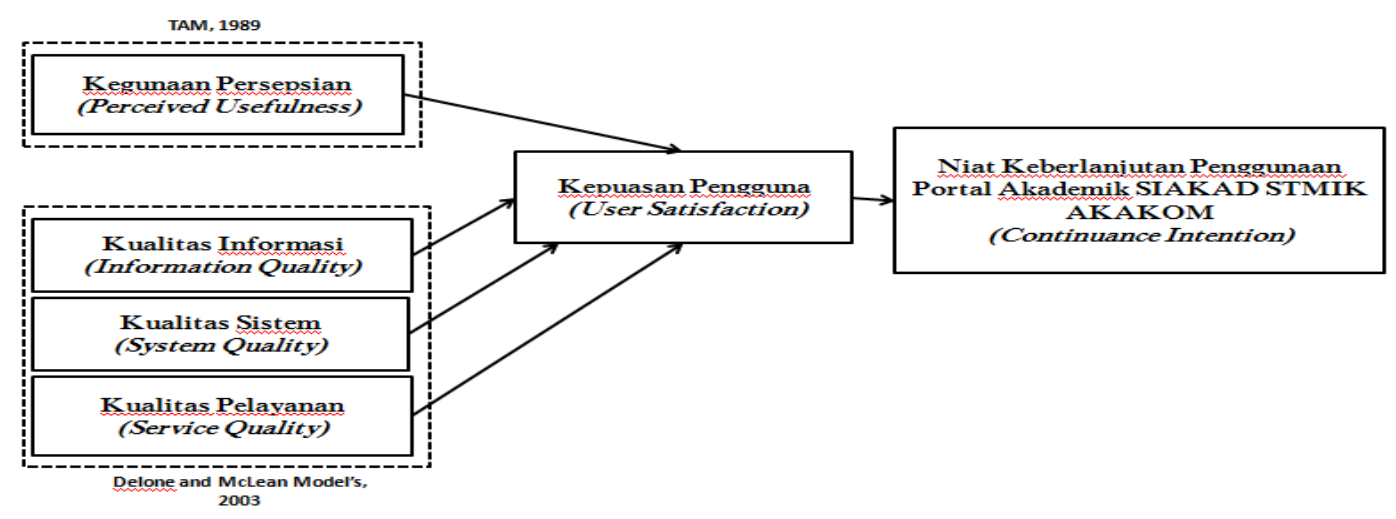

Gambar 1. Model Penelitian

Terdapat 5 (lima) hipotesis yang dikembangkan dari model penelitian tersebut, hipotesis yang pertama adalah kegunaan persepsian (perceived usefulness) Portal Akademik SIAKAD STMIK AKAKOM berpengaruh positif terhadap kepuasan pengguna (user satisfaction). Hipotesis kedua adalah kualitas informasi (information quality) Portal Akademik SIAKAD STMIK AKAKOM berpengaruh positif terhadap kepuasan pengguna (user satisfaction). Hipotesis ketiga adalah kualitas sistem (sistem quality) Portal Akademik SIAKAD STMIK AKAKOM berpengaruh positif terhadap kepuasan pengguna (user satisfaction). Hipotesis keempat adalah kualitas pelayanan (service quality) Portal Akademik SIAKAD STMIK AKAKOM berpengaruh positif terhadap kepuasan pengguna (user satisfaction), dan yang kelima adalah kepuasan pengguna (user satisfaction) terhadap Portal Akademik SIAKAD STMIK AKAKOM berpengaruh positif terhadap niat keberlanjutan penggunaan Portal Akademik SIAKAD STMIK AKAKOM (Continuance Intention).

Teknik Analisis Data

Kriteria sampel yang digunakan dalam penelitian ini adalah seseorang yang pernah mengakses Portal Akademik SIAKAD STMIK AKAKOM . Prosedur pengujian dan teknik analisis data adalah yang dilakukan sebagai berikut:

1. Analisis kualitatif

Analisis kualitatif digunakan untuk menganalisa dan menginterpretasikan data hasil kuesioner yang ditunjukkan dalam tabel frekuensi sehingga dapat digunakan dalam pengambilan keputusan.

2. Analisis kuantitatif

Analisis kuantitatif menggunakan Partial LeastSquare (PLS). Sampel dalam jumlah kecil dan asumsi normalitas tidak akan menja dimasalah bagi PLS karena menggunakan metode bootstraping. Dalam analisis kuantitatif akan dilakukan dengan pengujian pengukuran (outer model) dan juga dengan pengujian struktural (inner model) 
III. HASIL

\section{A. Profil Responden}

Data responden dalam penelitian ini diambil berdasarkan kriteria bahwa responden adalah pengguna SIAKAD STMIK AKAKOM. Media yang digunakan dalam mengumpulkan data responden adalah melalui kuesioner yang langsung diisi responden dengan media kertas. Berikut ringkasan data responden :

TABEL I.

\begin{tabular}{ccc}
\multicolumn{3}{c}{ DESKRIPSI RESPONDEN } \\
\hline \hline Jenis Kelamin & Jumlah & Persentase \\
\hline Laki-laki & 40 & 55 \\
Perempuan & 33 & 45 \\
Total & 73 & 100 \\
\hline Usia (tahun) & Jumlah & Persentase \\
\hline Kurang dari 19 & 7 & 10 \\
Antara 19 - 25 & 62 & 85 \\
Lebih dari 26 & 4 & 5 \\
Total & 73 & 100 \\
\hline Pekerjaan & Jumlah & Persentase \\
\hline Karyawan & 4 & 5 \\
Mahasiswa & 69 & 95 \\
Total & 73 & 100 \\
\hline Pendidikan & Jumlah & Persentase \\
\hline S2 atau sedang S2 & 1 & 1 \\
S1 atau sedang S1 & 7 & 10 \\
Sedang D3 atau D3 kebawah & 65 & 89 \\
Total & 73 & 100 \\
\hline Periode Mengakses Portal & Jumlah & Persentase \\
\hline Kurang dari 1 tahun & 25 & 34 \\
Antara 1 - 2 tahun & 31 & 43 \\
Antara 2 - 5 tahun & 16 & 22 \\
Lebih dari 5 tahun & 1 & 1 \\
Total & 73 & 100 \\
\hline Frekuensi Mengakses Portal & Jumlah & Persentase \\
\hline Antara 2 - 5 kali & 1 & 1 \\
Antara 6 -10 kali & 2 & 3 \\
Lebih dari 10 kali & 70 & 96 \\
Total & 73 & 100 \\
\hline \hline Sumber: Data Kuesioner & &
\end{tabular}

\section{B. Statistik Deskriptif}

Statistik deskriptif digunakan untuk memberikan gambaran mengenai hasil pengumpulan data mengenai variabel-variabel. Nilai terendah suatu distribusi data merupakan nilai minimum. Gambaran mengenai variabelvariabel penelitian Kegunaan Persepsian (perceived usefulness/PU), Kualitas informasi (information quality/IQ), Kualitas sistem (sistem quality/SQ), Kualitas pelayanan (service quality/SVQ), Kepuasan pengguna (user satisfaction/USF), Niat Keberlanjutan Penggunaan SIAKAD STMIK AKAKOM (Continuance Intention/CI) pada angka kisaran teoritis dan kisaran sesungguhnya, mean dan standar deviasi dapat dilihat pada Tabel I. berikut ini.

TABEL II.

ANALISIS DESKRIPTIF

\begin{tabular}{lccccc}
\hline \hline \multicolumn{1}{c}{ Variabel } & Kisaran teoritis & Kisaran Aktual & Mean Teoritis & Mean Aktual & Std. Deviasi \\
\hline Kegunaan Persepsian (PU) & $5-30$ & $9-25$ & 17,5 & 18,36 & 2,90 \\
Kualitas informasi (IQ) & $2-12$ & $3-9$ & 7 & 6,88 & 1,46 \\
Kualitas sistem (SQ) & $5-30$ & $6-23$ & 17,5 & 17,41 & 3,46 \\
Kualitas pelayanan (SVQ) & $3-18$ & $7-15$ & 10,5 & 10,62 & 1,65 \\
Kepuasan pengguna (USF) & $3-18$ & $3-14$ & 10,5 & 10,60 & 2,22 \\
Niat Keberlanjutan (CI) & $3-18$ & $3-15$ & 10,5 & 10,37 & 2,05 \\
\hline \hline Sumber: Output SPSS & & & &
\end{tabular}

Pada Tabel I. dapat dilihat bahwa respon responden terhadap variabel cukup baik seperti dengan nilai rata-ratanya lebih dari 3 atau nilai rata-ratavariabel tergolong tinggi yang berarti variabel dalam penelitian ini mendapatrespon positif dari responden.

\section{Pengujian Model Pengukuran (Outer Model)}

Model pengukuran untuk uji validitas konstruk dan reliabilitas dilakukan sebelum menguji model penelitian. Validitas konvergensi diukur menggunakan nilai loading factor indikator untuk masing-masing konstruk. Setiap indikator harus memiliki loading factor lebih dari 0,70 [3] sehingga dapat dikatakan valid. Berdasarkan kriteria tersebut, indikator-indikator yang nilai loadingnya kurang dari 0,70 didrop dari analisis. Model penelitian awal serta daftar loading factor masing-masing indikator adalah seperti yang tercantum dalam Gambar 2. dan Tabel II. 
Hasil dari outer loading untuk melihat tingkat validitas indikator dengan nilai loading factor diatas 0,7 ditunjukkan pada Gambar 7. Tabel II. Memuat nilai loading factor,yang bernilai dibawah 0,7 di drop / dihapus dari model.

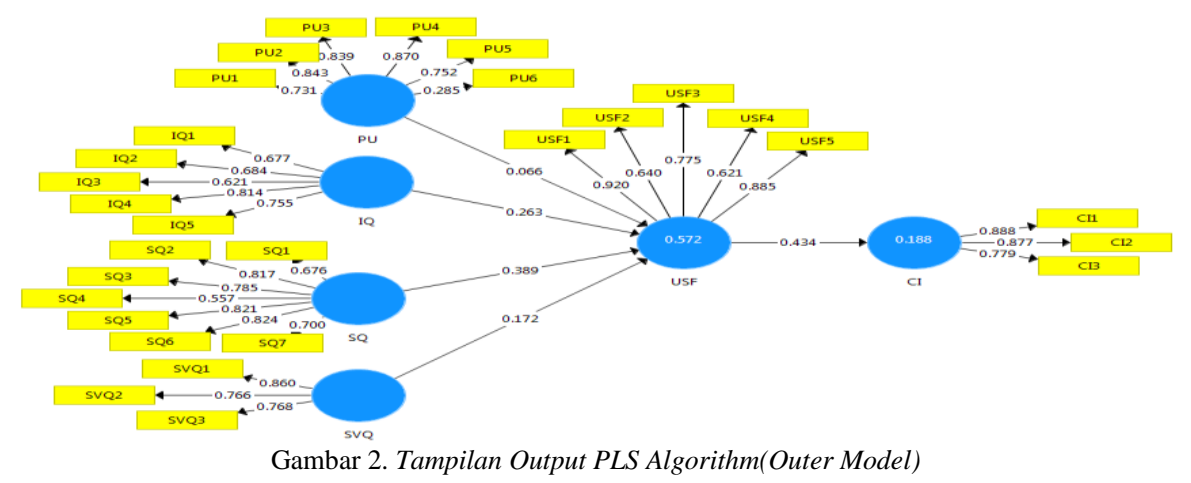

TABEL III.

\begin{tabular}{|c|c|c|c|c|c|c|}
\hline & $\overline{\mathrm{CII}}$ & 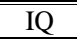 & $\overline{\mathrm{PU}}$ & 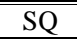 & PSVQ & "USF \\
\hline CI1 & 0,888 & & & & & \\
\hline CI2 & 0,877 & & & & & \\
\hline $\mathrm{CI} 3$ & 0,779 & & & & & \\
\hline IQ1 & & 0,677 & & & & \\
\hline IQ2 & & 0,684 & & & & \\
\hline IQ3 & & 0,621 & & & & \\
\hline IQ4 & & 0,814 & & & & \\
\hline IQ5 & & 0,755 & & & & \\
\hline PU1 & & & 0,731 & & & \\
\hline PU2 & & & 0,843 & & & \\
\hline PU3 & & & 0,839 & & & \\
\hline PU4 & & & 0,870 & & & \\
\hline PU5 & & & 0,752 & & & \\
\hline PU6 & & & 0,285 & & & \\
\hline SQ1 & & & & 0,676 & & \\
\hline SQ2 & & & & 0,817 & & \\
\hline SQ3 & & & & 0,785 & & \\
\hline SQ4 & & & & 0,557 & & \\
\hline SQ5 & & & & 0,821 & & \\
\hline SQ6 & & & & 0,824 & & \\
\hline SQ7 & & & & 0,700 & & \\
\hline SVQ1 & & & & & 0,860 & \\
\hline SVQ2 & & & & & 0,766 & \\
\hline SVQ3 & & & & & 0,768 & \\
\hline USF1 & & & & & & 0,920 \\
\hline USF2 & & & & & & 0,640 \\
\hline USF3 & & & & & & 0,775 \\
\hline USF5 & & & & & & 0,621 \\
\hline USF6 & & & & & & 0,885 \\
\hline
\end{tabular}

Berdasarkan hasil dari outer loading pada Gambar 1. dan Tabel II. masih terdapat tingkat nilai loading factor dibawah 0,7 yang ditulis dengan warma merah terdiri dari item IQ1 sebesar 0,677, IQ2 sebesar 0,684, IQ3 sebesar 0,621, PU6 sebesar 0,285, SQ1 sebesar 0,676, SQ4 sebesar 0,557, USF2 sebesar 0,640 dan USF4 sebesar 0,621, sehingga item tersebut masih harus di drop / dihapus dari model karena belum valid.

Hasil pengolahan data dengan PLS setelah item IQ1, IQ2, IQ3, PU6, SQ1, SQ4, USF2 dan USF4 setelah di drop/dihapus dari model dapat dilihat pada gambar Gambar 3. dan Tabel III. berikut ini.

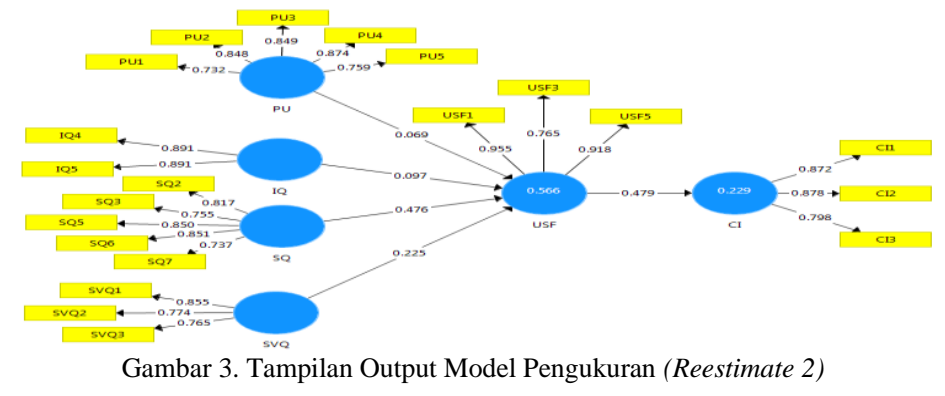


Berikut adalah Tabel IV. yang memuat loading factor setelah item IQ1, IQ2, IQ3, PU6, SQ1, SQ4, USF2 dan USF4 di drop/dihapus dari model.

Berdasarkan hasil pengolahan data dengan PLS 3 setelah item IQ1, IQ2, IQ3, PU6, SQ1, SQ4, USF2 dan USF4 di drop/dihapus dari model menunjukkan bahwa semua indikator yang digunakan dalam penelitian memiliki nilai loading factor diatas 0,70 . Dengan demikian berarti semua indikator yang digunakan dalam penelitian ini adalah valid.

TABEL IV.

\begin{tabular}{|c|c|c|c|c|c|c|}
\hline & CI & $\begin{array}{l}\mathrm{IQ} \\
\end{array}$ & PU & $\begin{array}{l}\text { SQ } \\
\end{array}$ & $\begin{array}{l}\text { SVQ } \\
\end{array}$ & USF \\
\hline CI1 & 0,872 & & & & & \\
\hline $\mathrm{CI} 2$ & 0,878 & & & & & \\
\hline $\mathrm{CI} 3$ & 0,798 & & & & & \\
\hline IQ4 & & 0,891 & & & & \\
\hline IQ5 & & 0,891 & & & & \\
\hline PU1 & & & 0,732 & & & \\
\hline PU2 & & & 0,848 & & & \\
\hline PU3 & & & 0,849 & & & \\
\hline PU4 & & & 0,874 & & & \\
\hline PU5 & & & 0,759 & & & \\
\hline SQ2 & & & & 0,817 & & \\
\hline SQ3 & & & & 0,755 & & \\
\hline SQ5 & & & & 0,850 & & \\
\hline SQ6 & & & & 0,851 & & \\
\hline SQ7 & & & & 0,737 & & \\
\hline SVQ1 & & & & & 0,855 & \\
\hline SVQ2 & & & & & 0,774 & \\
\hline SVQ3 & & & & & 0,765 & \\
\hline USF1 & & & & & & 0,955 \\
\hline USF3 & & & & & & 0,765 \\
\hline USF5 & & & & & & 0,918 \\
\hline
\end{tabular}

Pengujian validitas konvergensi juga dapat dilakukan dengan melihat nilai Average Variance Extracted (AVE). Apabila setiap konstruk AVE bernilai lebih besar dari 0,5 maka tidak ada permasalahan validitas konvergensi pada model yang diuji. Pada Tabel V. dapat dilihat bahwa nilai setiap konstruk yang digunakan dalam penelitian ini memiliki nilai lebih besar dari 0,5, dengan demikian model yang di uji tidak memiliki permasalahan validitas konvergensi atau semua konstruk dalam penelitian ini dikatakan valid.

TABEL V.

HASIL AVERAGE VARIANCE EXTRACTED (AVE)

\begin{tabular}{cc}
\hline \hline Konstruk & AVE \\
\hline CI & 0,723 \\
IQ & 0,794 \\
PU & 0,663 \\
SQ & 0,645 \\
SVQ & 0,639 \\
USF & 0,780 \\
\hline Sumber: Hasil Output SmartPLS 3.0
\end{tabular}

TABEL VI.

HASIL AKAR AVERAGE VARIANCE EXTRACTED (AVE)

\begin{tabular}{ccc}
\hline \hline Konstruk & AVE & Akar AVE \\
\hline CI & 0,723 & 0,850 \\
IQ & 0,794 & 0,891 \\
PU & 0,663 & 0,814 \\
SQ & 0,645 & 0,803 \\
SVQ & 0,639 & 0,799 \\
USF & 0,780 & 0,833 \\
Sumber: Hasil Output SmartPLS 3.0
\end{tabular}

Sumber: Hasil Output SmartPLS 3.0

Berdasarkan pengujian validitas konvergensi tidak ditemukan adanya permasalahan, sehingga dapat dilanjutkan dengan melakukan pengujian validitas diskriminan (discriminant validity). Validitas diskriminan dapat di uji dengan membandingkan akar dari Average Variance Extracted (AVE) untuk setiap konstruk dengan nilai korelasi antar konstruk dengan konstruk lainnya dalam model seperti pada Tabel VI.

Pengujian validitas diskriminan dilakukan dengan membandingkan akar AVE untuk setiap konstruk dengan korelasi antar konstruk lainnya dalam model. Model mempunyai validitas diskriminan yang cukup jika akar AVE untuk setiap konstruk lebih besar daripada korelasi antara konstruk dengan dengan konstruk lainnya dalam model. Tabel VII. berikut menunjukkan perbandingan nilai akar AVE dengan korelasi antar konstruk.

TABEL VII.

LATENT VARIABLE CORRELATION DAN AKAR AVE

\begin{tabular}{ccccccc}
\hline \multicolumn{7}{c}{ LATENT } \\
\hline Konstruk & CI & IQ & PU & SQ & SVQ & USF \\
\hline CI & 0,850 & & & & \\
IQ & 0,356 & 0,891 & & & \\
PU & 0,380 & 0,404 & 0,814 & & \\
SQ & 0,379 & 0,488 & 0,545 & 0,803 & & \\
SVQ & 0,445 & 0,508 & 0,436 & 0,713 & 0,799 & 0,883 \\
USF & 0,479 & 0,471 & 0,466 & 0,721 & 0,644 &
\end{tabular}


Berdasarkan perbandingan pada Tabel VII. antara korelasi antar konstruk dengan akar AVE dapat disimpulkan bahwa indikator yang digunakan dalam penelitian ini mayoritas memiliki akar AVE untuk setiap konstruk yang lebih besar daripada korelasi antara konstruk dengan dengan konstruk lainnya. Sehingga indikator dalam penelitian ini memenuhi kriteria validitas diskriminan.

Metode lain yang digunakan untuk menguji validitas diskriminan dengan melihat tabel Cross Loading seperti pada Tabel VIII. berikut ini.

TABEL VIII.

HASIL CROSS LOADING

\begin{tabular}{llllllll}
\hline \hline \multicolumn{2}{c}{ Konstruk } & CI & IQ & PU & SQ & SVQ & USF \\
\hline CI1 & $\mathbf{0 , 8 7 2}$ & 0,319 & 0,280 & 0,359 & 0,414 & 0,467 \\
C12 & $\mathbf{0 , 8 7 8}$ & 0,264 & 0,289 & 0,232 & 0,254 & 0,311 \\
CI3 & $\mathbf{0 , 7 9 8}$ & 0,311 & 0,394 & 0,347 & 0,429 & 0,409 \\
IQ4 & 0,269 & $\mathbf{0 , 8 9 1}$ & 0,380 & 0,419 & 0,564 & 0,421 \\
IQ5 & 0,365 & $\mathbf{0 , 8 9 1}$ & 0,341 & 0,450 & 0,341 & 0,419 \\
PU1 & 0,345 & 0,220 & $\mathbf{0 , 7 3 2}$ & 0,459 & 0,345 & 0,366 \\
PU2 & 0,222 & 0,323 & $\mathbf{0 , 8 4 8}$ & 0,362 & 0,323 & 0,401 \\
PU3 & 0,369 & 0,369 & $\mathbf{0 , 8 4 9}$ & 0,527 & 0,371 & 0,459 \\
PU4 & 0,334 & 0,460 & $\mathbf{0 , 8 7 4}$ & 0,488 & 0,451 & 0,370 \\
PU5 & 0,258 & 0,241 & $\mathbf{0 , 7 5 9}$ & 0,349 & 0,258 & 0,238 \\
SQ2 & 0,217 & 0,344 & 0,410 & $\mathbf{0 , 8 1 7}$ & 0,531 & 0,583 \\
SQ3 & 0,149 & 0,316 & 0,268 & $\mathbf{0 , 7 5 5}$ & 0,615 & 0,536 \\
SQ5 & 0,423 & 0,482 & 0,625 & $\mathbf{0 , 8 5 0}$ & 0,619 & $\mathbf{0 , 6 4 4}$ \\
SQ6 & 0,401 & 0,432 & 0,554 & $\mathbf{0 , 8 5 1}$ & 0,579 & $\mathbf{0 , 5 9 8}$ \\
SQ7 & 0,308 & 0,370 & 0,289 & $\mathbf{0 , 7 3 7}$ & 0,521 & $\mathbf{0 , 5 2 8}$ \\
SVQ1 & 0,446 & 0,481 & 0,303 & 0,585 & $\mathbf{0 , 8 5 5}$ & $\mathbf{0 , 5 1 5}$ \\
SVQ2 & 0,301 & 0,310 & 0,373 & 0,498 & $\mathbf{0 , 7 7 4}$ & $\mathbf{0 , 5 0 7}$ \\
SVQ3 & 0,318 & 0,423 & 0,368 & 0,624 & $\mathbf{0 , 7 6 5}$ & $\mathbf{0 , 5 1 9}$ \\
USF1 & 0,440 & 0,437 & 0,501 & 0,688 & 0,640 & $\mathbf{0 , 9 5 5}$ \\
USF3 & 0,176 & 0,203 & 0,116 & 0,486 & 0,415 & $\mathbf{0 , 7 6 5}$ \\
USF5 & 0,557 & 0,528 & 0,504 & 0,698 & 0,608 & $\mathbf{0 , 9 1 8}$ \\
\hline \hline
\end{tabular}

Berdasarkan Tabel VIII. dapat dilihat korelasi konstruk CI dengan indikatornya lebih tinggi dibandingkan korelasi dengan kontruk lainnya, demikian juga dengan konstruk yang lain korelasi dengan indikatornya lebih tinggi. Hal tersebut berarti bahwa konstruk laten memprediksi indikator pada blok mereka lebih baik dibandinggan dengan indikator lainnya, sehingga tidak terdapat permasalahan pada validitas diskriminan.

Pada penelitian ini metode uji reliabilitas yangdigunakan adalah Composite Reliability karenalebih baik untuk dalam mengestimasi konsistensi internal suatu konstruk[4]. Rule of thumb nilai alpha atau Composite Reliability harus lebih besar dari 0,7 meskipun nilai 0,6 masih dapat diterima pada studi yang sifatnya eksploratory [5]. Hasil uji reliabilitas konstruk dapat dilihat pada Tabel IX. berikut.

TABEL IX.

\begin{tabular}{cc} 
HASIL COMPOSITE RELIABILITY \\
\hline \hline Konstruk & $\begin{array}{c}\text { Composite Reliability } \\
\text { Kriteria }:>0,70\end{array}$ \\
\hline CI & 0,887 \\
IQ & 0,885 \\
PU & 0,907 \\
SQ & 0,901 \\
SVQ & 0,841 \\
USF & 0,913 \\
\hline \hline Sumber: Hasil Output SmartPLS 3.0
\end{tabular}

TABEL X. HASIL $R$-SQUARE

\begin{tabular}{cc}
\multicolumn{2}{c}{ HASIL $R$-SQUARE } \\
\hline \hline Konstruk & $R$-Square \\
\hline CI & 0,229 \\
USF & 0,566 \\
\hline \hline \multicolumn{2}{c}{ Sumber: Hasil Output SmartPLS 3.0 }
\end{tabular}

Berdasarkan hasil pada Tabel IX. nilai Composite Reliability dari masing-masing konstruk adalah diatas 0,7, dengan demikian pengukur yang dipakai dalam penelitian ini reliable.

\section{PEMBAHASAN}

Inner Model menggambarkan hubungan antara variabel laten berdasarkan pada substantive theory. Inner Model disebut juga inner relation, structural model dan substantive theory. Melalui proses bootstrapping, parameter uji $T$-statistic diperoleh untuk memprediksi adanya hubungan kausalitas. Pengujian inner model atau model struktural dilakukan untuk mengetahui hubungan antara konstruk, seperti yang telah dihipotesiskan dalam penelitian ini.

Model struktural dievaluasi dengan dengan menggunakan $R$-Square untuk konstruk dependen. Langkah penilaian model PLS dimulai dengan melihat $R$-Square untuk setiap variabel dependen yang interpretasinya sama dengan interpretasi pada regresi. Perubahan nilai $R$-Square dapat digunakan untuk menilai pengaruh variabel laten independen tertentu dengan variabel laten dependen dan apakah mempunyai pengaruh substantif. Hasil $R$ Square dalam penelitian ini dapat diihat pada Tabel X. berikut. 
Pada Tabel X. menunjukkan bahwa nilai R-Square untuk variabel CIadalah sebesar 0,229 yang berarti bahwa variance CI dijelaskan oleh variabel USF sebesar $22,9 \%$ dan sisanya $77,1 \%$ dijelaskan oleh variabel lain diluar penelitian ini. Nilai R-Square untuk variabel USF adalah sebesar 0,566 yang berarti bahwa varian USFdijelaskan oleh variabel PU, IQ, SQ, dan SVQsebesar 56,6\% dan sisanya sebesar 43,4\% dijelaskan oleh variabel lain diluar penelitian.

Apabila nilai $R^{2}$ lebih besar dari 0,2 maka dapat diinterpretasikan bahwa prediktor laten memiliki pengaruh besar pada level struktural. $R$-square model PLS dapat dievaluasi dengan melihat $Q$-square predictive relevance $\left(Q^{2}\right)$ untuk model variabel, dalam mengukur seberapa baik nilai observasi yang dihasilkan oleh model dan juga estimasi parameternya. Model dinilai mempunyai nilai predictive relevance jika nilai $Q$-square lebihbesar dari 0 (nol), dan sebaliknya model dinilai kurang memiliki predictive relevance jika nilai $Q$-square kurang dari 0 (nol). Dengan demikian jika hasil perhitungan memperlihatkan nilai $Q$-square lebih dari 0 (nol), maka model layak dikatakan memiliki nilai prediktif yang relevan.Uji $Q$-Square predictive relevance $\left(Q^{2}\right)$ pada Inner Model diukur menggunakan rumus sebagai berikut:

$\mathrm{Q} 2=1-\left(1-\mathrm{R}_{1}^{2}\right)\left(1-\mathrm{R}_{2}^{2}\right) \ldots \ldots\left(1-\mathrm{Rp}^{2}\right)$

$\mathrm{R}_{1}{ }^{2}, \mathrm{R}_{2}{ }^{2} \ldots \mathrm{Rp}^{2}$ adalah $R$ - Square variabel endogen dalam model. Interpretasi $\mathrm{Q}^{2}$ sama dg koefisien determinasi total pada analisis jalur (mirip dengan $\mathrm{R}^{2}$ pada regresi). Uji $Q$-Square predictive relevance $\left(Q^{2}\right)$ dalam penelitian ini adalah sebagai berikut.

$$
\mathrm{Q} 2=1-(1-0,229)(1-0,566)=0,6
$$

Hasil uji $Q$-Square predictive relevance $\left(Q^{2}\right)$ tersebut menghasilkan nilai 0,80 yang berarti bahwa model mempunyai nilai predictive relevance.

Uji Goodness of Fit (GoF) merupakan uji kecocokan model, dan harus dicari secara manual karena pada PLSSEM tidak menyediakan menu khusus untuk menghitung GoF. Hasil uji GoF dikategorikan small berarti nilai GoF sebesar 0,1, medium berarti nilai GoF sebesar 0,25, dan kategori besar berarti nilai GoF adalah 0,38 (Tenenhaus, 2005). Uji Goodness of Fit (GoF) dalam penelitian ini adalah sebagai berikut.

$$
\begin{aligned}
& \text { GoF }=\sqrt{\overline{\overline{A V E} \times \overline{R^{2}}}} \\
& G o F=\sqrt{\overline{4,244} \times \overline{0,795}}=\sqrt{0,707 \times 0,40}=0,53
\end{aligned}
$$

Berdasarkan pengujian R2, Q2 dan GoF terlihat bahwa model yang dibentuk adalah robust, dengan demikian pengujian hipotesa dapat dilakukan. Ukuran signifikansi keterdukungan hipotesis dapat digunakan perbandingan nilai $T$-table dan $T$-statistic[3]. Jika $t$-statistic lebih tinggi dibandingkan nilat-table, berarti hipotesis terdukung atau diterima. Penelitian menggunakan tingkat keyakinan 95 persen (alpha 5 persen) maka nilai $T$-table untuk hipotesis satu ekor (one tailed) adalah lebuh besar dari 1,64.

Signifikansi model prediksi dalam pengujian model struktural dilihat dari nilai tstatistic antara variabel independen ke variabel dependen dalam tabel Path coefficient.Tabel XI. merupakan hasil pengolahan data uji signifikansi dengan SmartPLS versi 3.

TABEL XI.

TOTAL EFFECT (MEAN, STDEV, T-VALUES)

\begin{tabular}{ccccc}
\hline \hline Konstruk & $\begin{array}{c}\text { Original Sample } \\
(\mathrm{O})\end{array}$ & $\begin{array}{c}\text { Sample } \\
\text { Mean }(\mathrm{M})\end{array}$ & $\begin{array}{c}\text { Standard Deviation } \\
(\text { STDEV })\end{array}$ & $\begin{array}{c}\text { T Statistics } \\
(0 / S T D E V)\end{array}$ \\
\hline PU -> USF & 0,069 & 0,080 & 0,102 & 0,677 \\
IQ -> USF & 0,097 & 0,104 & 0,095 & 1,022 \\
SQ -> USF & 0,476 & 0,465 & 0,148 & 3,228 \\
SVQ -> USF & 0,225 & 0,233 & 0,106 & 2,126 \\
USF -> CI & 0,479 & 0,505 & 0,110 & 4,345 \\
\hline \hline
\end{tabular}

Sumber: Hasil Output SmartPLS 3.0

Gambar 4. berikut ini menunjukkan hasil dari pengolahan data Bootsrapping.

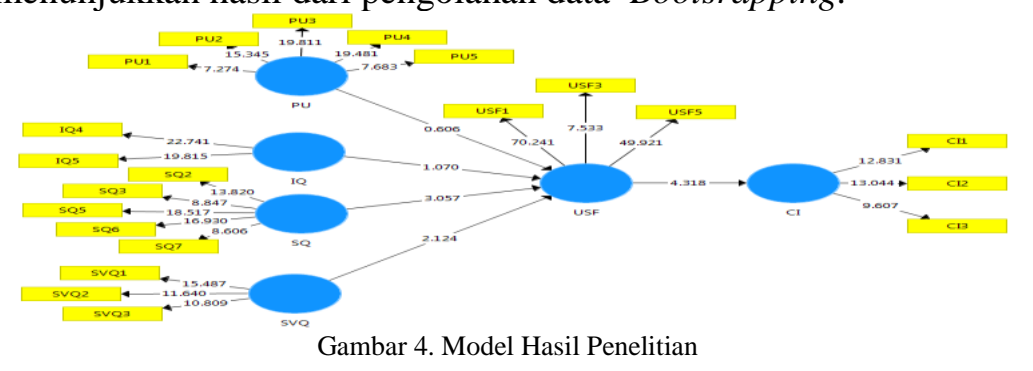

Pengujian Hipotesis 1 bertujuan untuk mengetahui apakah terdapat hubungan positif antara Kegunaan Persepsian (perceived usefulness/PU)denganKepuasan Pengguna (user satisfaction/USF) menggunakan SIAKAD STMIK AKAKOM. Dari hasil pengolahan data didapatkan bahwa nilai koefisien path antara Kegunaan Persepsian (perceived usefulness/PU)denganKepuasan Pengguna (user satisfaction/USF)adalah sebesar 0,069 
dengan nilai t-satistik sebesar 0,677. Pada tingkat signifikansi 0,05 (t-statistik > t-tabel 1,64) maka hipotesis 1 yang menyatakan bahwa Kegunaan Persepsian (perceived usefulness/PU)memiliki hubungan positif dengan Kepuasan Pengguna (user satisfaction/USF) adalah tidak terdapat pengaruh yang signifikan antara Kegunaan Persepsian (perceived usefulness/PU)denganKepuasan Pengguna (user satisfaction/USF). Hal ini dibuktikan dari besarnya nilai t-statistik untuk konstruk PEOU terhadap konstruk ATU masih di bawah 1,96 yaitu hanya sebesar 0,677. Hasil penelitian mengenai hubungan positif antara antara Kegunaan Persepsian (perceived usefulness/PU)denganKepuasan Pengguna (user satisfaction/USF) menggunakan SIAKAD STMIK AKAKOM sejalan dengan penelitian sebelumnya yang dilakukan oleh [6], bahwa Kegunaan Persepsian tidak menjadi prediktor yang lebih baik terhadap kepuasan dan niat berkelanjutan menggunakan sistem.

Pengujian Hipotesis 2 bertujuan untuk mengetahui apakah terdapat pengaruh positif antara Kualitas Informasi (Information Quality/IQ) denganKepuasan Pengguna (User Satisfaction/USF) menggunakan SIAKAD STMIK AKAKOM.Dari hasil pengolahan data didapatkan bahwa nilai koefisien path antara Kualitas Informasi (Information Quality/IQ) dengan Kepuasan Pengguna (User Satisfaction/USF)adalah sebesar 0,097 dengan nilai t-satistik sebesar 1,022. Pada tingkat signifikansi 0,05 (t-statistik > t-tabel 1,96) maka hipotesis 2 yang menyatakan bahwa Kualitas Informasi (Information Quality/IQ) memiliki hubungan yang positif denganKepuasan (Satisfaction / SF)adalah tidak terdapat pengaruh yang signifikan, hal ini dibuktikan dari besarnya nilai t-statistik untuk konstruk PEOU terhadap konstruk ATU masih di bawah 1,96 yaitu hanya sebesar 1,022. Hasil penelitian mengenai hubungan positif antara Kualitas Informasi (Information Quality) denganKepuasan (Satisfaction / SF) menggunakan SIAKAD STMIK AKAKOM tidak sejalan dengan penelitan sebelumnya, yaitu penelitian yang telah dilakukan oleh Syaifullah dan Dicky (2016), kualitas informasi yang paling baik yaitu menyediakan website yang dapat dipercaya sedangkan yang paling buruk yaitu website tidak menyediakan informasi yang detail.

Pengujian Hipotesis 3 bertujuan untuk mengetahui apakah terdapat pengaruh positif antara Kualitas Sistem (sistem quality/SQ) denganKepuasan Pengguna (User Satisfaction/USF) menggunakan SIAKAD STMIK AKAKOM.Dari hasil pengolahan data didapatkan nilai koefisien path antara Kualitas Sistem (sistem quality/SQ) denganKepuasan Pengguna (User Satisfaction/USF) adalah sebesar 0,476 dengan nilai t-satistik sebesar 3,228. Pada tingkat signifikansi 0,05 (t-statistik > t-tabel 1,69) maka hipotesis 3 yang menyatakan bahwa Kualitas Sistem (sistem quality/SQ) memiliki hubungan positif denganKepuasan Pengguna (User Satisfaction/USF) adalah signifikan dan terdukung secara statistik oleh data yang ada.Hasil penelitian mengenai adanya hubungan positif antara Kualitas Sistem (sistem quality/SQ) denganKepuasan Pengguna (User Satisfaction/USF) menggunakan SIAKAD STMIK AKAKOM sejalan dengan penelitan sebelumnya yang dilakukan oleh [7]yaitu kualitas informasi harus dianggap sebagai isu penting selama melakukan desain sistem e-learning karena pengguna cenderung menggunakannya saat mereka merasakan bahwa informasi yang diberikan oleh sistem jelas, mudah dipahami dan relevan untuk pekerjaan mereka. Selain itu kualitas interaksi pelayanan yang paling baik yaitu website memberikan keamanan sedangkan yang paling buruk yaitu website tidak memberikan kemudahan untuk menyampaikan masukkan (feed back).

Pengujian Hipotesis 4 bertujuan untuk mengetahui apakah terdapat pengaruh positif antara Kualitas Pelayanan (Service Quality/SQ) denganKepuasan Pengguna (User Satisfaction/USF) menggunakan Portal Akademik SIAKAD STMIK AKAKOM.Dari hasil pengolahan data didapatkan bahwa nilai koefisien path antara Kualitas Pelayanan (Service Quality/SQ) denganKepuasan Pengguna (User Satisfaction/USF) menggunakan Website STMIK AKAKOM(Continuance Intention) adalah sebesar 0,225 dengan nilai t-satistik sebesar 2,126. Pada tingkat signifikansi 0,05 (t-statistik > t-tabel 1,64) maka hipotesis 4 yang menyatakan bahwa Kualitas Pelayanan (Service Quality/SQ) memiliki hubungan yang positif denganKepuasan Pengguna (User Satisfaction/USF) menggunakan Portal Akademik SIAKAD STMIK AKAKOM adalah signifikan dan terdukung secara statistik oleh data yang ada.Hasil penelitian mengenai adanya hubungan positif antara Kualitas Pelayanan (Service Quality/SQ) denganKepuasan Pengguna (User Satisfaction/USF) sejalan dengan penelitian yang telah dilakukan oleh Roca[7]yaitu kualitas layanan,kualitas sistem dan kemudahan persepsian penggunaan juga berperan penting sehingga peran manajer harus mengembangkan sistem yang menyediakan layanan yang cepat dan andal dengan antarmuka interface yang baik sehingga mendorong orang untuk menggunakannya kembali.

Pengujian Hipotesis 5 bertujuan untuk mengetahui apakah terdapat pengaruh positif antara Kepuasan Pengguna (User Satisfaction/USF) denganniat keberlanjutan penggunaan Portal Akademik SIAKAD STMIK AKAKOM (Continuance Intention).Dari hasil pengolahan data didapatkan bahwa nilai koefisien path antara Kepuasan Pengguna (User Satisfaction/USF) denganniat keberlanjutan penggunaan Portal Akademik SIAKAD STMIK AKAKOM (Continuance Intention) adalah sebesar 0,479 dengan nilai t-satistik sebesar 4,345. Pada tingkat signifikansi 0,05 (t-statistik > t-tabel 1,96) maka hipotesis 5 yang menyatakan bahwa Kepuasan Pengguna (User Satisfaction/USF) memiliki hubungan yang positif denganniat keberlanjutan penggunaan Portal Akademik SIAKAD STMIK AKAKOM (Continuance Intention) adalah signifikan dan terdukung secara statistik oleh data 
yang ada.Hasil penelitian mengenai hubungan positif antara Kepuasan(Satisfaction) denganNiat Keberlanjutan menggunakan Portal Akademik SIAKAD STMIK AKAKOM(Continuance Intention) searah dan terdukung dengan hasil penelitian sebelumnya, yaitu penelitian yang telah dilakukan oleh Roca [7],niat kelanjutan pengguna ditentukan oleh kepuasan, yang pada gilirannya secara bersama-sama ditentukan oleh manfaat yang dirasakan, kualitas informasi, konfirmasi, kualitas pelayanan, sistem kualitas, persepsi kemudahan penggunaan dan penyerapan kognitif

\section{SIMPULAN DAN SARAN}

Berdasarkan penelitian yang telah dilakukan terdapat beberapa faktor-faktor penerimaan dan niat keberlanjutan penggunaan yang merupakan indikator kesuksesan penerapan SIAKAD di STMIK AKAKOM. Variabel Kualitas Informasi (Information Quality) dan Kualitas Sistem (System Quality/SQ) berdasarkan hasil analisis merupakan faktor yang berpengaruh terhadap Kepuasan Pengguna (User Satisfaction/USF) terhadap SIAKAD di STMIK AKAKOM. Sedangkan Niat keberlanjutan menggunakan (Continuance Intention) SIAKAD di STMIK AKAKOM ditentukan oleh Variabel Kepuasan Pengguna (User Satisfaction/USF) terhadap SIAKAD di STMIK AKAKOM.

Hasil penelitian ini dapat digunakan untuk memberikan informasi kepada divisi pengembangan Sistem Informasi mengenai faktor-faktor yang mempengaruhi SIAKAD STMIK AKAKOM dapat diterima dan digunakan secara berkelanjutan.

\section{REFERENSI}

[1] Davis, F. D. Perceived usefulness, perceived ease of use, and user acceptance of information technology. MIS Quarterly, 13(3), 319-340. 1989.

[2] DeLone, W.H., McLean, E.R.: Information Systems Success: The Quest for the Dependent Variable. Information SystemsResearch 3 (1), 60-95 (1992.

[3] Hartono M.J, dan Abdillah W. 2009. Konsep dan Aplikasi PLS (Partial least Square) Untuk Penelitian Empiris. Penerbit BPFE, Yogyakarta.[3] Werts, C. E., Linn, R. L., \& Jöreskog, K. G. (1974). Intraclass reliability estimates: Testing structural assumptions.Educational and Psychological Measurement, 34(1), 25-33.

[4] Werts, C. E., Linn, R. L., \& Jöreskog, K. G. (1974). Intraclass reliability estimates: Testing structural assumptions.Educational and Psychological Measurement,34(1), 25-33

[5] Hair, J.F., et al., 2006. Multivariate data analysis. 6th ed.Upper Saddle River, New Jersey: Pearson Education.

[6] Ralph, K.J.H., and James, T.T.C. Extended conceptualisation of perceived usefulness: empirical test in the context of informationsystem use continuance.Behaviour \& Information Technology.Vol. 31, No. 5, May 2012, 525-540. 2012.

[7] Roca, et al, 2006. Understanding e-learning continuance intention: An extension of the Technology Acceptance Model. International Journal of Human Computer Studies, ISSN: 1071-5819:64, 683-696 